\title{
PAY SATISFACTION AND ORGANIZATIONAL POLITICS AS PREDICTORS OF QUALITY OF WORK LIFE AMONG GOVERNMENT EMPLOYEES
}

\author{
MATHEW O. OLASUPO, ERHABOR S. IDEMUDIA, GANIYAT S. AROWOSEGBE, \\ DAMILARE A. FAGBENRO \\ Department of Psychology, Obafemi Awolowo University, Ile-Ife, Osun State, Nigeria \\ North-West University - Mafikeng Campus: Mmabatho North West, South Africa
}

(C) 2019 Mathew O. Olasupo, Erhabor S. Idemudia, Ganiyat S. Arowosegbe, Damilare A. Fagbenro

This is an open access article distributed under the Creative Commons Attribution-NonCommercial-NoDerivs license (http://creativecommons.org/licenses/by-nc-nd/3.0/)

DOI: 10.1515/eras-2019-0003

\begin{abstract}
The study investigated the predictive role of pay satisfaction and organisational politics on quality of work life. Herzberg's Two-Factor Theory was used as a theoretical framework in this study. Cross sectional survey research design was adopted. Data were collected from 429 respondents consisting of $($ Females $=231(53.8 \%)$, Males $=198(46.2 \%)($ Mean age $=39.14$, S.D $=12.07)$ via a simple random and convenience sampling techniques. Work-Related Quality of life scale (WRQLS), Pay Satisfaction Questionnaire (PSQ) and Perceived Organisational Politics Scale (POPS) were used as instrument for data collection. Data collected were analysed using Pearson moment correlation (PPMC) and Multiple Regression analysis. There was significant positive relationship between pay satisfaction and quality of work life. Positive relationship was found between organisational politics and the quality of work life. Finally, pay satisfaction and organisational politics jointly predict quality of work life. These findings have implications for putting up psychological interventions aim at improving the quality of work life of government employees.
\end{abstract}

\section{Keywords}

Quality of work life, Pay satisfaction, Organizational politics, Government employees.

\section{Introduction}

Quality of work life in recent time has attracted interest among scholars, practitioners and organizational researchers. This is because employees in the workplace are one of the vital instruments that move the organisation in the right direction; hence, it is essential that their quality of work life is given high priority. According to Srivastava and Kanpur (2014), quality of work life refers to the level of satisfaction individuals witness within their place of work. It encompasses various aspects of work life, i.e. work itself, working conditions, working skill, rewards and otherwise. Xu and Van a der Heijden (2005) also defined quality of work life as an atmosphere that adds to employee satisfaction, which can be measured through the emotions workers have towards their jobs, co-workers and organisations. On the other hand, Sirgy, Efraty, Siegel and Lee (2001) define quality of work life as worker fulfillment toward different needs such as resources, activities and outcomes stemming from partaking in the workplace. From this definition, it is important that employees have a sound mind at work in order to utilize their full potential and to put more value on the progress of the organisation. This is because a satisfied employee is an asset to the organisation as such 
Mathew O. Olasupo, Erhabor S. Idemudia, Ganiyat S. Arowosegbe, Damilare A. Fagbenro, Pay satisfaction and organizational politics as predictors of quality of work life among government employees

DOI: 10.1515/eras-2019-0003

may ensure full productivity of the organisation.

Studies (Mosandeghrad, Ferlie and Rosenberg 2011; Monfaredniya, 2008; Taher, 2013) have established that inadequate level of quality of work life have result to human resources productivity loss and inefficiency. It is unfortunate that in the last couple of years, the issue of quality of work life among government employees in Nigeria has become worrisome (Owolabi 2015). The wellbeing of employees has been in severe threat, coupled with the state of economic downfall in the country which has also contributed negatively to the quality of work life of an ordinary government worker in Nigeria. The days when the remunerations, such as salaries and allowances, bonuses received by government workers were a source of envy for the employees in the private sectors are gone. Official quarters, free medical treatment, transportation schemes, adequate training, liberal working hours, prompt payment of salaries, guaranteed pension and gratuity scheme, secured jobs and other benefits were all that public servants enjoyed, that really flourished their quality of work life. Currently, things have changed drastically in the life of government employees in Nigeria. Civil servants now live in abject poverty, as a result of delay or non-payment of salary and other benefits. Anecdotal evidence shows that Ondo state civil servants, who remain integral part of public sector, are not left out of this menace as they still have to be paid salary arrears, biased political practices, unhealthy working environment and so on. These have implication on their wellbeing as most of these workers cannot adequately cater for their families' wellbeing, such as paying school fees for their children as well as the provision of basic amenities for them. These workers have developed diverse psychological challenges such as depression, anxiety and post-traumatic stress disorders when they perceive that their work is not satisfactory (Nanjundeswaraswamy, 2013). This problem invariably has contributed to the poor quality of work life among government employees.

There are ample of studies that have considered predictors of quality of work life such as emotional intelligence (Tamini and Chadha, 2018), organizational value (de Campos and Marín Rueda, 2017), organizational pressure (Ogunsanya and Olorunfemi 2012), organizational culture and leadership style (Owolabi 2015) and organizational climate, leadership style and emotional intelligence (Adeyemo, Terry and Lambert 2015) among university, bank and health workers, however none of the studies considered the predictive role of pay satisfaction and organizational politics on quality of work life especially among civil servants. Hence, a gap in the literature exists, that this present study hopes to fill in by investigating the predictive role of pay satisfaction and organizational politics on quality of work life especially among government employees in a developing nation such as Nigeria. The outcome of this study would broaden managerial knowledge on possible interventions programs that would help improve the quality of work life among government employees.

Pay satisfaction referred to the sum of favorable or unfavorable feelings that employees have toward their salary (Ismail and Zakaria, 2009). In addition, pay is also used to compensate workers for their input in the workplace. Workers who are satisfied with their pay/salary tend to have a good quality of work life. On another hand, employees who are dissatisfied with their pay often experience a decrease in commitment to the job, increase stealing or theft as well as increase job turnover (Ezeh and Olawale, 2017). Invariably, when all these problems are not effectively managed in the workplace, these can lead to unstable psychological and emotional wellbeing of employees. Workers who are satisfied with their jobs will want to retain their jobs, such that they will not have any reason to quit their jobs. If pay is tied to employees' performance, then high quality of work will be recorded (Armstrong, 2006). According to Mitchall, Holton and Lee (1993), employee stays in an organisation if enough satisfaction is derived from pay policy or leaves the organisation when no satisfaction is derived from pay policy. The inability of employees to have a desirable pay 
Mathew O. Olasupo, Erhabor S. Idemudia, Ganiyat S. Arowosegbe, Damilare A. Fagbenro, Pay satisfaction and organizational politics as predictors of quality of work life among government employees

satisfaction has made many Nigerian civil workers often agitate for an increase in their salary. Many times Nigerian workers have engaged in industrial disputes to press home their grievances and compel their employers to look into their matter (Asekun, 2015). When government employees perceive their pay as unsatisfactory, it is often expected that they have low job satisfaction which invariably could lead to unhealthy quality of work life.

Another variable that is relevant to this study is organizational politics. Bodla and Danish (2010) defined organizational politics as behaviour and action of an individual which tends to sustain one's self interest in the workplace. In another dimension, Ferris, Fedor, Chachere and Pondy (2000) also define organisational politics as behaviours that are tactically considered to maximize short-term or long-term self-interest that may be valuable or harmful to the organisations and employees. Gone are days in civil service where appointments or managerial positions were based on individual's performances, years of experience and educational attainment. In the recent times, workplace politics have changed most of the organisational structure, in a way that civil servants believe that an employee can get to the top of their career through godfatherism, nepotism or friendship with those in power.

The issue of due process in civil service has reduced drastically because nepotism has taken over almost everything in the public sector. Civil servants who are non-beneficiaries of political manipulations in the workplace, but choose to remain in the organisation, may react with negative work attitudes and behaviours toward the organisation (Ferris, Russ and Fandt, 2002; Valle and Perrewe, 2000). However, when employees perceive organization's politics as not favourable to them, they feel cheated and unsupportive. Such an employee may have low job satisfaction, which invariably leads to an unhealthy quality of work life. It is from the foregoing that this study examines the predictive role of pay satisfaction and organisational politics on quality of work life among government employees.

\section{Theory, empirical literature review and statement of hypotheses. Theoretical framework}

This study is anchored on the theoretical framework of Herzberg's Two-Factor Theory. Herzberg's Two-Factor Theory states that employee motivation is attained when workers are confronted with challenging but pleasant work where one can achieve, grow and demonstrate responsibility and advance in the organization. Quality of work life involves some level of satisfaction with one's job. For example, government employees who perceive poor pay satisfaction couple with high organizational politics tend to lose interest in their job, which tends to affect the quality of work life. Therefore, understanding the role of pay satisfaction and organizational politics will have implications for how psychological interventions can be organized to improve the quality of work life.

\section{Empirical literature review. Pay satisfaction and quality of work life}

Ezeh and Olawale (2017) investigated the relationship between pay satisfaction and quality of work life among 377 workers, working in Awka metropolis, Anambra State, Nigeria. The results revealed that pay satisfaction had no significant connection with the quality of work life among the sampled respondents. Yongmei and Jianki (2015) found an association between reward satisfaction and quality of work life of factory workers in China. Also, Rizqi and Ridwan (2015) examined the impact of affective commitment and pay satisfaction on the quality of work life. Data was gathered among 150 employees of an automotive manufacturing company in Indonesia. Path analysis was adopted to test the data. Results showed that pay satisfaction significantly influences the quality of work life.

Olawale, Ilesanmi and Olarewaju (2016) investigated the influence of pay satisfaction and quality of work life among employees of Lagos State University. Results showed a positive relationship between pay satisfaction and quality of work life. Ogunsanya and 
Mathew O. Olasupo, Erhabor S. Idemudia, Ganiyat S. Arowosegbe, Damilare A. Fagbenro, Pay satisfaction and organizational politics as predictors of quality of work life among government employees

Olorunfemi (2012) investigated organisational pressure and pay satisfaction on the quality of work life of among 3.640 women working in four purposively selected institutions in Lagos metropolis. The study found that pay satisfaction has a significant positive influence on the quality of work life among the sampled respondents. Also, Owolabi (2015) examined pay satisfaction and leadership type on quality of work life among 284 employees from private and public work organisations in Ekiti State, Nigeria. The study found that there is a joint influence of pay satisfaction and leadership type on quality of work-life among the sampled respondents. Ahmad and Gelaidan (2013) in their study found a significant positive connection between pay satisfaction, turnover intentions and quality of work life.

Suleiman (2013) examined pay satisfaction and quality of work life among 245 workers. It was found that pay satisfaction did not have any relationship on the quality of work life among the sampled respondent. Anyaoku (2016) investigate momentary satisfaction on quality of work life among 175 workers working in various libraries in Nigeria. The study showed that there was a significant influence of momentary satisfaction on quality of work life among the sampled respondents.

Okoh, Onuoha and Akhigbe (2016) investigated the association of quality of work life and organisational commitment in the public sector in Rivers State. A cross-sectional survey was used to target a sample of 797 public servants. The study found that adequate and fair compensation to a great extent influences organisational commitment and quality of work life. From the reviewed literature, no study till date has investigated predictive role of pay satisfaction on quality of work life using data from government employees, especially in developing country such as Nigeria.

\section{Organisational politics and quality of work life}

Ojokuku and Akanbi (2014) examined the role of organisational politics and quality of work life among 197 employees of a paints manufacturing company in Lagos, Nigeria. The study found that organisational politics have a positive link with quality of work life among the sampled respondent. Ikon and Ohue (2016) examined organizational politics and quality of work life among 305 employees. The study found that organisational politics have a positive association with quality of life.

Abubakar, Chauhan and Kura (2014) in their study investigated the association between perceived organisational politics and quality of work life among one hundred and seventy-five registered nurses. It was found that perceived organisational politics have a significantly positive association with the quality of work life. Fanimehin and Popoola (2013) examined the role of organisational politics on quality of work life of 450 library personnel in the Federal Civil Service in Nigeria. The data were analysed using correlation coefficient analysis. There was a significant relationship between organisational politics and quality of work life of the respondents. Wangui and Muathe (2014) examined the relationship between perception of organisational politics and employee well-being in Kenyan business organisation. The descriptive survey research design was used by the researchers. They concluded that organisational politics have a negative relationship with employee wellbeing.

Ugwu, Ndugba, Okoroji and Kalu (2014) examined the relationship between organisational politics and employees' quality of work life. Findings revealed that bad political behaviour influences employees' quality of work life negatively and lowers organisational productivity, while good political behaviour influences employees' quality of work life positively and increases organisational productivity. Adebusuyi, Olasupo and Idehen (2013) examined the perception of organisational politics among three hundred and seventy-two staff of Obafemi Awolowo University. Results of the study showed out of the six dimensions of perception of organisational politics only one dimension (Go Along to Get 
Ahead) was perceived most by workers of Obafemi Awolowo University. Furthermore, the result revealed that non-academic workers significantly perceived organisational politics more than the academic staff. Nwizia, Ojiabo and Alagah (2015) investigated perceived organisational politics and employee's job satisfaction among 274 health workers in Rivers State. The cross-sectional research design was adopted. The study found a significant association between organisational politics and job satisfaction among the health workers. Thus, it is expected that pay satisfaction and organizational politics jointly and independently predict quality of work life among government employees

\section{Statement of hypotheses}

1. There will be a significant positive relationship between pay satisfaction and quality of work life among government employees.

2. There will be a significant negative relationship between organizational politics and quality of work life among government employees.

3. There will be significant joint and independent prediction of pay satisfaction and organisational politics on quality of work life among government employees.

\section{Methodology}

\section{Design}

Cross-sectional survey research design was used. This design was considered suitable because the objective of the study was predictive in nature and data were collected from participants at a single point in time. The independent variables are pay satisfaction and organizational politics while the dependent variable is the quality of work life.

\section{Population and setting}

The population of this study consists of Ondo State civil servants working in Akoko North East, Akure North and Ile-Oluji/Oke-Igbo local government area of Ondo state. The reason why these settings were chosen was that large numbers of civil servants can be found in these three local government areas. Also, the settings were easily accessible to the researcher.

\section{Sample and sampling technique}

A pre-survey visit done by the researcher to the Ondo State Civil Service Commission, Akure, revealed that the total population of Ondo State civil servants is 48.527. The sample size for this study was determined using Krejcie and Morgan (1970) sample size formula.

The simple random sampling technique of the balloting type was used to select one local government each from the three senatorial districts of Ondo state. Thereafter, the study used a convenience sampling technique to select the respondents from the three local governments at a different point in time.

\section{Participants}

The participants' age was between 20 to 56 years with a mean age of 39.14 yrs and standard deviation of 12.07. In terms of gender representation, it was observed that 231 $(53.8 \%)$ of total respondents were females, while $198(46.2 \%)$ were males. Respondents' religion showed that $303(70.6 \%)$ of total respondents identified themselves as Christians, 118 $(27.5 \%)$ as Muslims, while eight (1.9\%) were traditionalists. In terms of educational qualification, $24(5.6 \%)$ of total respondents completed only primary/secondary education, 97 
Mathew O. Olasupo, Erhabor S. Idemudia, Ganiyat S. Arowosegbe, Damilare A. Fagbenro, Pay satisfaction and organizational politics as predictors of quality of work life among government employees

DOI: 10.1515/eras-2019-0003

(22.6\%) claimed they were NCE/OND holders, $244(56.9 \%)$ reported that they were BSC/HND holders, $26(6.1 \%)$ are MSc holders, while only one $(0.2 \%)$ claimed qualification at Ph.D. level. However, the respondents' marital status, showed that $63(14.7 \%)$ of total respondents were single, $358(83.4 \%)$ were married, $3(0.7 \%)$ were separated, $1(0.2 \%)$ were divorced and $40.9 \%$ ) were widowed. Respondent cadre showed that $93(21.7 \%)$ were junior workers while majority $289(67.4 \%)$ were in the senior cadre. Finally, the distribution of respondents by job tenure showed that $85(19.8 \%)$ had spent between 1-4 years in service, nine $(2.1 \%)$ had spent $1-5$ years in service, nine $(2.1 \%)$ had spent $10-14$ years while majority $326(76.0 \%)$ of respondents had spent 15 years and above.

\section{Instruments}

A questionnaire was administered in order to document the bio-data of the respondents, which include age, gender, job tenure etc. The questionnaire further included a quality of work life scale, pay satisfaction scale and perception of organisational politics scale.

\section{Quality of work life scale}

Quality of work life was measured using the work-related quality of life scale (WRQLS) developed by Van Laar, Edwards and Easton (2007). The scale consisted of 24 items. Sample items in the scale were "I have a clear set of goals and aims to enable me to do my job" and "I work in a safe environment". Each of the 24 items of QWLS was phrased in a sentence with a 5-point Likert scale response format ranging from strongly agree $=1$ to strongly disagreed $=5$. The Cronbach's alpha for the scale is 0.91 . The present study got a Cronbach coefficient of 0.87 .

\section{Pay satisfaction scale}

Pay satisfaction was captured using the 18-item pay satisfaction questionnaire developed by Heneman and Schwab (1985). Sample items in the satisfaction with pay level subscale were "my overall level of pay" (Heneman and Schwab, 1985). The response format was 5- point Likert format ranging from 1-very dissatisfied to 5-very satisfied. The present study has a Cronbach reliability coefficient of 0.92 . A high score on the scale means high pay satisfaction while low scores translate to low pay satisfaction.

\section{Organisational politics scale}

Organisational politics were measured using perceived organisational politics scale developed by Kacmar and Carlson (1997). The scale consisted of 15 items. The scale is rated on a 5 point Likert responds pattern ranging from 1-strongly agreed to 5 -strongly disagree. The sample items were "People in this organisation attempt to build them up by tearing others down" and "Promotions around here are not valued much because they are so political". The scale has a reliability coefficient of 0.93 . The internal consistency reliability estimate (Cronbach alpha) was reported as 0.88 as reported by Adebusuyi, Olasupo and ldehen (2013). Within the present study, this scale had an overall Cronbach coefficient of 0.84 .

\section{Procedure}

Introduction letter was obtained from the Department of Psychology, Obafemi Awolowo University introducing the researchers to the study settings. Thereafter, the researcher got permission from the Head of Departments/staff in the three local governments area visited for the study. Respondents were thereafter educated on the purpose and objectives 
Mathew O. Olasupo, Erhabor S. Idemudia, Ganiyat S. Arowosegbe, Damilare A. Fagbenro, Pay satisfaction and organizational politics as predictors of quality of work life among government employees

DOI: $10.1515 /$ eras-2019-0003

of the study. They were also informed that participation in the study was voluntary and that they were free to withdraw from the study whenever they felt uncomfortable to continue. The participants were also given assurance of confidentiality in their responses. The questionnaire was distributed to the participants with the help of two research assistants. A total of 450 questionnaires were distributed to the respondents at the close of work at a different point in time. However, only 429 questionnaires were found usable, as 15 of the questionnaires were not returned and 6 were badly filled, totaling about 21 questionnaires that were void. The retrieved questionnaires were subjected to SPSS version 23 for appropriate statistical analysis.

\section{Results}

Hypothesis one

Table 1: Pearson Product Moment correlation showing the relationship between pay satisfaction and quality of work life

\begin{tabular}{lccccc}
\hline Variables & Mean & S.D & df & r & p-val \\
\hline Pay satisfaction & 42.75 & 13.42 & 427 & & \\
Quality of work life & 67.66 & 14.68 & & $.42^{* *}$ & $<.05$ \\
**. Correlation is significant at the 0.01 level (2-tailed). & & &
\end{tabular}

From the table presented above, the results revealed that there was a significant positive relationship between pay satisfaction and quality of work life among government employees $(\mathrm{r}=$ 0.42 , df $=427, \mathrm{p}<.05)$. The result implied that employees who are high on pay satisfaction significantly report high quality of work life.

\section{Hypothesis Two}

Table 2: Pearson Product Moment correlation showing the relationship between organisational politics and the quality of work life

\begin{tabular}{lccccc}
\hline Variables & Mean & S.D & df & $\boldsymbol{r}$ & $\boldsymbol{p}$-val \\
\hline Organisational politics & 41.98 & 10.67 & 427 & \multirow{2}{*}{. } & \\
Quality of work life & 67.66 & 14.68 & & & $<.05$ \\
\hline
\end{tabular}

**Correlation is significant at the 0.01 level (2-tailed).

The result above showed that there was a significant positive relationship between organisational politics and the quality of work life $(r=0.25, \mathrm{df}=427, \mathrm{p}<.05)$. The result implies that employees with high organisational politics significantly report high quality of work life.

\section{Hypothesis three}

Table 3: Summary of Multiple Regression Analysis showing the predictive role of Pay Satisfaction, Organisational Politics on Quality of Work Life

\begin{tabular}{lccccccc} 
Predictors & $\mathbf{B}$ & $\mathbf{T}$ & $\mathbf{P}$ & $\boldsymbol{R}$ & $\boldsymbol{R}^{\mathbf{2}}$ & $\boldsymbol{F}$ & $\boldsymbol{P}$ \\
\hline Pay satisfaction & .38 & 8.03 & $<.05$ & .45 & .19 & 49.80 & $<.05$ \\
Organisational politics & .12 & 2.45 & $<.05$ & & & & \\
\hline
\end{tabular}

The result above revealed that pay satisfaction and organisational politics jointly predict the quality of work life $\left\{\mathrm{R}^{2}=19 \%, \mathrm{~F}(2,426)=49.80, \mathrm{p}<.05\right\}$ among government employees. When combined, the respondents' pay satisfaction and organisational politics accounted for $19 \%$ of the change observed in the quality of work life among government employees. This 
Mathew O. Olasupo, Erhabor S. Idemudia, Ganiyat S. Arowosegbe, Damilare A. Fagbenro, Pay satisfaction and organizational politics as predictors of quality of work life among government employees

revealed that the collective presence of pay satisfaction and organisational politics has a significant prediction on the quality of work life among government employees. The result also revealed that pay satisfaction $(\beta=0.38, \mathrm{t}=8.03, \mathrm{p}<.05)$ and organisational politics $(\beta=$ $0.12, \mathrm{t}=2.45, \mathrm{p}<.05$ ) have a significant independent influence on the quality of work life among Ondo State civil servants.

\section{Discussion}

The current study investigates the extent to which pay satisfaction and organizational politics predicts the quality of work life among government employees. As predicted in hypothesis one, there was a significant positive relationship between pay satisfaction and quality of work life, this implies that employees with high pay satisfaction significantly report high quality of work life. This finding was in line with Issa, Ahmad and Gelaidan (2013), who found that there is a significant positive relationship between pay satisfaction, turnover intentions and quality of work life. This finding was also in line with Mba and Ikemefun (2012), who found that the greater satisfaction with pay, the less likely is the turnover intention and the higher the employee quality of work life. Another similar study is the one done by Zahra, Irum, Mir and Chishti (2013), who found that high pay has a positive influence on the quality of work life. The justification why the finding was so is because government employees are often faced with various financial responsibilities such as children school fees, accommodation fees, transportation, providing shelters and clothing etc. All these can only be effectively attended to if there is an increase in the salary and salaries are paid to workers as at when due. An employee who is able to solve these financial problems will want to give his best to the organisation while an employee who perceives his or her pay as not been satisfactory might have challenge coping with all these responsibilities which invariably affect their quality of work life

The second hypothesis revealed that there was a significant positive relationship between organisational politics and the quality of work life. This means that government workers who have high organisational politics report high quality of work life. The finding was in accordance with Ojokuku and Akanbi (2014), who found that organisational politics have a positive relationship with the quality of work life among the sampled respondent. This study finding is similar to the study done by Okpara (2004), who found that organisational politics have a positive relationship with the quality of work. This finding was also consistent with $\mathrm{Hu}$ (2010), who found a significant positive relationship between perceived organisational politics and the quality of work life. Ikon and Ohue (2016) found that organisational politics have a positive relationship on the quality of work life among the sampled respondent. The plausible reason why the finding of this hypothesis was so might be the fact that civil servants in Nigeria, including Ondo State government workers, use organizational politics to get and enhance whatever they want, especially in a competitive environment where material and human resource are scarce and hard to come by in the workplace, employee who only engages in political maneuvering are the set of employee who enjoys this limited resource which invariably enhances their quality of work life in the workplace. Furthermore, another reason why the finding was so can be explained by Moorhead and Griffin's (2004) claim that political behaviour is a vital part of most government functions. The environment in which Ondo State civil servants work contributes greatly to the practice of political behaviour which invariably makes them be satisfied in the workplace.

The third hypothesis revealed that there was a joint and independent influence on the quality of work life among civil servants. The finding was in line with Burke (2003), who asserted that the basic determinants of quality of work life among employees are pay 
Mathew O. Olasupo, Erhabor S. Idemudia, Ganiyat S. Arowosegbe, Damilare A. Fagbenro, Pay satisfaction and organizational politics as predictors of quality of work life among government employees

satisfaction and perceived politics. Another study done by Wibowo (2010) examined the combined influence of job politics and pay satisfaction among 231 employees. The study found that job politics and pay satisfaction have a joint effect on the quality of work life among the sampled respondent. The finding was also in line with a study done by Amadi (2010), who found out that organisational politics and work motivation have a joint influence on work commitment and satisfaction among 302 teachers in Enugu state, Nigeria. The study of Choong (2011) showed that dissatisfaction with pay and organisational politics significantly have a joint effect on the quality of work life among selected employee in a public firm.

\section{Conclusion, implications and directions for future study}

The study concluded that pay satisfaction has a significant positive relationship with the quality of work life, meaning that employees who report high pay satisfaction have a higher quality of work life. The study also concluded that organisational politics have a positive relationship with the quality of work life; this implies that civil servants who perceive high organizational politics report high quality of work life. Finally, the study concluded that there is a joint and independent prediction of pay satisfaction and organisational politics on quality of work life among government employees. These findings have practical and theoretical implications. Since it has been found that pay satisfaction and organisational politics have a significant relationship with the quality of work life among civil servants. This implies that the quality of work life among civil servants will continue to suffer if these variables are not given adequate attention. In view of this, Government should look for the best possible techniques to foster employee pay satisfaction, because increase in pay satisfaction of an employee leads to an increase in the quality of work life. This result also has implication for supervisors, such as they can strategically inculcate political behaviour into the workplace setting; an increase in organisational politics will lead to an increase in the quality of work life among employees. Also, organisational/industrial psychologist and human resource manager should find a way to inculcate both organisational politics and pay satisfaction in the workplace, which will improve the quality of work life of the employee.

The study, therefore, recommends that Organizational/industrial psychologists should design intervention programs tailored toward improving pay satisfaction and organisational politics, in order to help foster a better quality of work life among government employees. Government at all levels should at all-time seek employee opinion through survey, or feedback concerning their satisfaction level relating to their pay; employees whose pay is not satisfactory to him or her should be improved upon such that it will bring a positive quality of work life for the employee and also help improve the productivity level of the organisation. The supervisor should inculcate political behaviour in the workplace environment such that it encourages employees to engage in good political behaviour that will positively improve their quality of work life and also take the right steps to curb potentially dysfunctional political behaviour that can be detrimental to the organisation and employee wellbeing. Theoretically, the findings of this study lend support to Herzberg's Two-Factor Theory. In term of support, this study supported that pay satisfaction and perceived organisational politics plays a major role in the improvement of wellbeing which improves the quality of work life of civil servants. This is the first study to our knowledge that applied Herzberg's Two-Factor Theory states to the quality of work life in a developing country such as Nigeria.

Despite the relevance of this study, it is still faced with some limitations; the first is that only four local governments in Ondo state, Nigeria were used for this study which makes the sample size to be relatively small. This has implication for generalization the findings to other government employees in Nigeria. Secondly, getting the participants of the study to fill 
Mathew O. Olasupo, Erhabor S. Idemudia, Ganiyat S. Arowosegbe, Damilare A. Fagbenro, Pay satisfaction and organizational politics as predictors of quality of work life among government employees

DOI: $10.1515 /$ eras-2019-0003

the questionnaires was very tasking. Therefore, to enhance the strength of this study, future studies can improve the setting and sample, inculcating some form of incentives. Future studies can investigate the role of psychological factors such as organizational culture and personality traits on quality of work life, with emphasis on comparative study on both public and private employees.

\section{REFERENCES}

Abubakar, E., Chauhan, S., and Kura, P. (2014). Relationship between perceived organisational politics, and quality of work life. Journal of Contemporary Research in Business, Vol. 4 No. 1, pp.156-170.

Adebusuyi, A. S., Olasupo, M. O., and Idehen, E. E. (2013). Analysis of the perception of organisational politics by employees of Obafemi Awolowo University, Ile-Ife, Nigeria. Bangladesh e-Journal of Sociology, Vol.10, No.1, pp.51-58

Adeyemo, D. A., Terry, D. L., and Lambert, N. J. (2015). Organizational Climate, Leadership Style and Emotional Intelligence as Predictors of Quality of Work Life among Bank Employees in Ibadan, Nigeria. European Scientific Journal, Vol. 11 No.4, pp.110- 30.

Ahmad, O., and Gelaidan, T. (2013). Relationship between pay satisfaction, turnover intentions and quality of work life. Journal of Couselling Psychology, No. 3, pp.45-67.

Anyaoku, E. N. (2016). Demographic determinants of quality of work life of Librarians working in Nigeria. International Journal of Advanced Library and Information Science, Vol.4, No.1, pp.312-323.

Armstrong, G. (2006). Handbook of affective science (619-642). Oxford, England: Oxford University Press

Asekun, B. (2015). Importance of pay to Nigeria worker. International Refereed Journal, Vol. No. 2, pp.43-50.

Bodla, M. A., and Danish, R. Q. (2010). The perceptions of organisational politics and work Performance: exploring the differences in public and private Sector. International Journal of Knowledge, Culture and Change Management, Vol. 8, No.4, pp. 123-132.

De Campos, M., and Marín Rueda, F. (2017). Effects of Organizational Values on Quality of Work Life. Paidéia, Vol 27, No. 67, pp. 65-75

Ezeh, L., and Olawale, Y. (2017). Pay satisfaction, job satisfaction and quality of work life as correlates of turnover intention among federal civil servants in Awka metropolis of Anambra state, South-East, Nigeria. International Journal of Advanced Multidisciplinary Research Reports. Vol. 2 Vol. 1, pp.3455.

Fanimehin, D., and Popoola, O. (2013). Effect of organisational politics on quality of life of library personnels. Industrial and Commercial Training, Vol.31, pp.9-12

Ferris, R., Adams, G., Kolodinsky, W., Hochwarter, A., and Ammeter, P. (2002). Perceptions of organisational politics: theory and research directions. In F. J. Yammarino and F. Dansereau (eds.) Research in Multilevel Issues, Vol. 1, The many faces of multi-level Issues, 179-254. Oxford, UK: JAI Press/Elsevier Science.

Ferris, R., Fedor, B., Chachere, G., and Pondy, R. (2000). Myths and politics in organisational context. Group and Organisation Studies, Vol. 14, pp.83-103.

Heneman, H., and Schwab, D. (1985). Pay satisfaction: its multidimensional nature and measurement. International Journal of Psychology, Vol. 20, pp. 129-141.

Ikon, M., and Ohue, A. (2016). Organisational politics and overall quality of life. International Journal of Business and Management Review, Vol.4, No7, 39-49.

Ismail, U., and Zakaria, E (2009). Pay satisfaction and Behaviour in the workplace. Journal of Counselling, No.2, pp.33-46

Kacmar, K., and Carlson, P. (1997). Perceptions of Organisational Politics Scale: Development and construct validation. Educational and Psychological Measurement, Vol 21, pp.193-205

Krejcie, R. V., and Morgan, D. W. (1970). Determining sample size for research activities. Educational and Psychological Measurement, Vol 30, pp. 607-610

Mitchell, R., Holtom, B., and Lee, W. (1993). How to keep your best employees: Developing an effective retention policy. The Academy of Management Executive, Vol. 23, No. 2, pp.96-109

Monfaredniya, N. (2008). Examination of relation between working life quality and vocational weariness of Tehran Azad Universities employees.MA thesis. Tehran IT University.

Nanjundeswaraswamy, T. S. (2013). Quality of work life of employees in private technical institutions. International Journal for Quality Research, Vol.7, No 3, pp.3-14.

Nwizia, U., Ojiabo, U., and Alagah, D. (2015). Relationship between organisational politics and quality of work life among health sectors in River state. International Journal of Advanced Academic Research /Social 
Mathew O. Olasupo, Erhabor S. Idemudia, Ganiyat S. Arowosegbe, Damilare A. Fagbenro, Pay satisfaction and organizational politics as predictors of quality of work life among government employees

DOI: $10.1515 /$ eras-2019-0003

\& Management Sciences, Vol. 3, No. 7, pp.34-66

Ogunsanya, M., and Olorunfemi, A. (2012). Organisational Pressure on Quality-of-worklife of Women in Tertiary Institutions in Lagos State, Nigeria. International Education Studies, Vol 5, No. 6, pp.36-49

Ojokuku, O., and Akanbi, T. (2014). Role of organisational politics and quality of work life. Journal of Educational and Social Research, Vol1, No.4, pp.57-70.

Okoh, H. O., Onuoha, B.C., and Akhigbe, J.O. (2016). Quality of work life among employees. International Journal of Novel Research in Humanity and Social Sciences, Vol.3, No 3, pp.35-44

Olawale, A. R., Ilesanmi, J. F., and Olarewaju, O. (2016). Relationship between job satisfaction, pay satisfaction, turnover intention and quality of work life. BVIMSR's Journal of Management Research, Vol.8, No.2, pp. 102-114.

Owolabi, A. (2015). Impact of organizational culture and leadership style on quality of work-life among employees in Nigeria. African Journal for the Psychological Study of Social Issues, Vol.18, No.1, pp.109-121.

Rizqi, A. N., and Ridwan, S. (2015). The effects of pay satisfaction and effect of commitment on turnover intention. International Journal of Research Studies in Psychology, No. 2, pp.57-70.

Sirgy, J. M., Efraty, D., Siegel, P., and Lee, D. (2001). A new measure of quality of work life based on need satisfaction and spillover theories. Social Indicators Research, Vol.55, No.3, 241-302.

Srivastava, S., and Kanpur, R. (2014). A Study on Quality of Work Life: Key Elements \& its Implications. Journal of Business and Management, Vol. 16, No.3, pp.54-59.

Suleiman, H. (2013). Pay satisfaction and quality of work life among employees. Journal of Behaviour, Vol 5, pp.45-67.

Tamini, B., and Chadha, K. (2018).Emotional Intelligence and Quality of Work Life between Iranian and Indian University Employees: A Cross-Cultural Study. International Journal of Psychology, Vol.12 No.1, pp. 91-117

Taher, A.M. (2013). Variations of quality of work life of academic professionals in Bangladesh. European Journal of Training and Development, Vol.37, No.6, pp.580-595.

Ugwu, S., Ndugba, Y., Okoroji, P., and Kalu, S. (2014). Impact of organizational politics on employees' quality of work life. Journal of General Management, Vol 34, No. 4, pp.51-66.

Van Laar, D., and Easton, S. (2010). Exploration of "pre-retirement bounce" in quality of working life and employee engagement. IWP Conference on Work, Wellbeing and Performance, Sheffield, UK. Abstract, 52.

Wangui, K., and Muathe, I. (2014). Relationship between perception of organizational politics, and employee wellbeing. Journal of Management Studies, Vol, 37, pp. 869-899

$\mathrm{Xu}$, Y., Van, D., and Heijden, B. (2005). The employee factor in the service-profit chain framework. Journal of International Consumer Marketing, doi.org/10.1300/J046v18n01_07

Yongmei, P., and Jianki, I. (2015). Reward satisfaction and quality of work life. Journal of Nursing, Vol5, pp.56-89 